\title{
Legal Issues in The Implementation of National Social Security System on Labour in Indonesia
}

\author{
Tedi Sudrajat ${ }^{*}$, Siti Kunarti ${ }^{2}$ and Abdul Aziz Nasihuddin ${ }^{3}$ \\ ${ }^{1}$ Department of Administrative Law, Faculty of Law Jenderal Soedirman University, Purwokerto, \\ Indonesia \\ ${ }^{2}$ Department of Administrative Law, Faculty of Law Jenderal Soedirman University, Purwokerto, \\ Indonesia \\ ${ }^{3}$ Department of Administrative Law, Faculty of Law Jenderal Soedirman University, Purwokerto, \\ Indonesia
}

\begin{abstract}
The Social Security System in Indonesia has been regulated by the government, and the program is managed by an agency called Social Insurance Administration Organization (BPJS). Associated with the existence of social security functions for workers, its practice presents a gap between what is expected and what is regulated. For this reason, it is therefore necessary to examine, firstly, what kind of legal protection of workers is covered by this national social security system managed in BPJS program and, secondly, what constraints are encountered in its implementation. This research is Juridical Normative one, with normative qualitative data analysis. The research finds that the social security is correlated not only with the welfare of employees who are assessed by the level of wages provided by the organization, rather it is also correlated with other factors in the form of health and safety assurance. In the broader context, social welfare is measured not only when the person is at work and gets social security benefits, rather the measure of his welfare is also applicable when the worker is not working and/or when they retire. On the basis of these, the social security program is an integral aspect of social security to which the government should give a legal protection.
\end{abstract}

\section{Introduction and Literature Review}

National Social Security System is a social security system established in Indonesia as set forth in Law Number 40 Year 2004. This social security is one form of social protection administered by the government of Republic of Indonesia to ensure that its citizens can fulfil their basic life needs as mandated in the UN Declaration on Human Rights Year 1948, ILO Convention No.102 Year 1952 and the preamble of 1945 Constitution of the Republic of Indonesia.

Workers are parts of the community who require social security in the effort of realizing their welfare. In relation to fulfilling this welfare, the obligation is not embedded only to

*Corresponding author: tedi.unsoed@gmail.com 
employers, rather it is also the government's responsibility to make a social security scheme and legal protection scheme for the provision of welfare for worker.

In principle, the national social security system shall be made using three "three-pillar paradigm" as recommended by ILO. These pillars include:

1. Social aid program for members of community who have no sources of finance or access to services which can fulfil their basic needs. This aid is given to members of community who are found to have urgent need, be affected by natural disaster(s) and social conflicts, suffer from disease, or lose their jobs. This aid fund is taken from National Budget and from local community fund.

2. The social insurance program of mandatory nature is funded by the contribution withdrawn from the companies and workers. The contribution payable by participants is determined based on their income/salary rate as well as a minimum living standard applicable to the community.

3. The insurance offered by the private sector is voluntary, which can be bought by participants if they want to have higher social coverage than the social security they obtain from the obligatory social insurance program contribution. The contribution for this private insurance program is varied according to the risk analysis of each participant.

In relation to the Worker's welfare, the measurement and guarantee are not just about the amount of wage or salary, rather it is also about the social security given by the employers to support the welfare for their workers and their family. The forms of social security for workers were previously governed based on Law Number 3 Year 1992 concerning Worker's Social Security (Jaminan Sosial Tenaga Kerja (JAMSOSTEK)) which set forth work accident insurance, life insurance, old-age insurance and health care insurance programs. In its development, on November 25, 2011 the government enacted Law Number 24 Year 2011 concerning National Social Security Administration Organization (BPJS) which was a public legal entity to administer social security program.

In its implementation, BPJS is divided into 2 parts, namely BPJSs for Health and Manpower. BPJS for Health is a transformation of Asuransi Kesehatan Indonesia (ASKES), a company which administers health insurance program. BPJS for Manpower is a transformation of Jaminan Sosial Tenaga Kerja (JAMSOSTEK), a company which administers the work insurance, life insurance, old-age insurance programs which is then added with one program to the BPJS for Manpower, i.e. retirement insurance. The issue point in relation to this National Social Security System is the relationship between its concept, implementation and evaluation. This is important to be studied since many workers have not had sufficient understanding on this National Social Security System and have not registered. Until the end of 2017, the number of workers registered as participants of BPJS for Manpower was still minimum. The Head of Supervisory Board of BPJS for Manpower, Guntur Witjaksono suggests that the fact that it still has low number of participants is because many workers have not known BPJS for Manpower. He adds that of around 112 million workforces, only 25 millions are participants of BPJS for Manpower. Furthermore, he acknowledges that it is not easy for the public or workers to understand BPJS for Manpower program.[1]

\subsection{Relationship between Legal Protection and Employment Social Security}

Legal protection has tight relationship with the meaning of law itself. Legal protection becomes one function of law existence. In this regard, law is created as a means or instrument to govern the rights and obligations of law subjects to allow these law subject to respectively perform their obligations well and to receive their rights reasonably. Additionally, the law also serves as a protector instrument for the law subjects. [2] 
To realize this legal protection in government administration context, it is important to note that the executor is the government. Workers as the parties who participate in the country's economic development deserve some protection from the government. The protection given by the country to workers is to ensure their welfare when they are still working until after they no longer work. Imam Soepomo divides worker protection into 3, they are

1. Economic protection, or a type of protection which deals with the efforts of providing workers with an adequate income to fulfil their family's need, including in case the worker fail to work due to something beyond their power. Such a protection is called as social security;

2. Social protection, or a protection related to social effort, the aim of which is to allow workers to enjoy and develop their life as a human being in general, and as a member of community and family; or commonly called as: work health;

3. Technical protection, or a type of protection which has something to do with the efforts of keeping workers from any accident which may be caused by work instruments or other equipment or by the materials being processed or made by the company; hereinafter, this type of protection is called as work safety. [3]

The economic protection, or commonly known as social security, deals with the numerous efforts the community and or government can do. These efforts made for workers are those in employment protection specifically intended for worker community who are the core of development power and who keep on encountering socio-economic risks, included in social insurance. Meanwhile, the objectives of social security for workers are:

As a means to provide basic protection for workers/labours to deal with economic/ social risks or certain events, such as:

1. Need for medical service;

2. Suspended, lost or decreased amount of income resulting from:

3. Illness;

4. Pregnancy;

5. Work accident and occupational illness;

6. Old age;

7. Disability;

8. Death of wage earner.

9. Responsibility for family and children.

As a means to achieve social goal by providing work convenience for workers/ labours who play a great role in the state development. [4]

Considering the foregoing, the very position of workers as the party working for a company certainly have the possibilities of being the party at loss or the weaker party than employers. It is this very position of workers which requires the immediate provision of protection from the government. This provision of protection for workers is also the government's duties to provide protection to any and all of its citizens with no exception, including workers.

\subsection{Social Security System for Workers}

Social security is directly governed in Indonesia's constitution in Article 28H paragraph (3) of 1945 Constitution, which states that "everyone is entitled to a social security which allows them to develop themselves intently as a dignified human being". Social security becomes a form of protection for every citizen from the risks possibly encountered such as accident, death or loss of income. These risks are highly likely to occur to anyone, including workers.

According to International Labour Organization (ILO), "Social security" in principle is a protection system provided by the community to its members through various attempts in 
dealing with economic or social risks which may result in the stoppage/significant decrease of income." [5]

One of the objectives of why social security is organized is to maintain people's purchasing power in the face of economic uncertainty. Based on the two objectives of social security previously stated, it can then be seen that the objective of social security is actually emphasized on the economic protection element. Three criteria should be fulfilled if an activity is to be said as a social security program:

1. The objectives are to provide medical treatment to recover from or to prevent illness, to provide income aid when a loss of part of or all of their income occurs, or to guarantee additional income for those in charge of family;

2. There is a law which governs the rights and obligations of the institution organizing the activity;

3. The activity is organized by a certain institution. [6]

Based on the foregoing, it can be seen that the objectives of social security, in addition to its economic benefit, is also to provide legal protection, income protection, and also medical treatment as an integral part in social security during and after their service period.

\section{Objective of the study}

This paper aims at synchronizing the concept, implementation and evaluation of national social security system related to employment rights. The weaknesses of this system will be analysed and revised and then implemented as a measurement of program success.

\section{Discussion}

In managing everything, the government should have a clear legal basis, because Indonesia is a state law. The arrangement given by the government can be called as government policy. Policy is a set of decisions made by political agents in the effort of setting goals and methods to achieve these goals.[7] Policy is a part of arrangement or action made by the government as implemented in the form of law products.

The concept of arrangement is a part of legal protection provision to the community, including workers. The importance of social security for workers becomes something Indonesian people had been aware of even before its independence. As has been a common knowledge, prior to its independence, workers were not call workers, they were called labour. Labour contains narrower meaning to it than worker, thus the protection provided to them had not covered everything. It was only from the beginning of independence that policies were established in regard to worker protection in the form of social security as set forth in the law.

As the industry in Indonesia develops with time, the policies governing social security for workers also develop. At the end of 2004, the government issued Law Number 40 Year 2004 concerning National Social Security System. The presence of this Law is related to Article 5 paragraph (1), Article 20, Article 28H paragraph (1), paragraph (2) and paragraph (3) and Article 34 paragraph (1) and paragraph (2) of amended 1945 Constitution.

Under the 1945 Constitution which mandated that a social security system for all Indonesian people should be developed and the explanation of Law Number 40 Year 2004 concerning National Social Security System (SJSN Law), Law Number 24 Year 2011 concerning Social Security Administration Organization (BPJS) are established.

In its implementation, a law can only be implemented and applied well once in a society a structure which allows its members to realize the ideal of such law has been in place.[8] The said structure is BPJS as the one playing the role of health insurer for workers in the effort of creating a mutually beneficial relationship between the relevant parties. The object of such relationship is healthcare for workers. Law No. 36 Year 2009 concerning Health sets 
forth the structure of community and states that everyone has the same rights to obtain access to resources in the field of health and receive a safe, high-quality, and affordable health care. On the contrary, everyone shares the obligation to participate in social health insurance program. In providing health services, the activities are divided into administrative, medical, medical supporting, and nursing services.

Having analysed the substance of health service by BPJS, it is found that in principle the SJSN Law has fundamentally changed the state's obligation in providing health insurance to people's obligation. People's right is changed into people's obligation. As a consequence, people lose their right to receive health insurance the state should have fulfilled. This is not in accordance with the provisions of Article $28 \mathrm{H}$ paragraph (3) and Article 34 paragraph (2) of 1945 Constitution which mandates the social security and health insurance as the citizen's rights which becomes the state's obligation to realize it.

The method of transferring obligation is done by imposing premium. The amount of premium itself is varied depending on the facilities promised by the commercial insurance company. The higher the contribution (premium) paid, the better the health service class to be received by the participants. The difference is that while the participation in other insurance is voluntary, workers are required to participate in this JKN. This is where the load is thought to be excessively too heavy for workers, particularly for formal and informal workers who receive salary below the (Regional) Minimum Wage. Furthermore, BPJS still impose administrative penalty in the form of fine for premium delayed payment. It is clear that it is not in accordance with the provisions of Article 4 paragraph $g$ of Law Number 8 Year 1999 concerning Customer Protection (Customer Protection Law), wherein it is stated that customers have the right to be treated and served well and honestly and nondiscriminatorily. In short, what actually happens is that there is no free lunch for workers. Every worker is required to pay the contribution, even when they are not ill or the fund is not used, they still have to pay the monthly premium contribution.

In regard to this premium imposition, the state hands over its authority to BPJS to provide the health benefit for workers. This service is used by using the service facilities provided both in the form of outpatient, hospitalization, home visit by health officers or other forms of activity of using this service which is based on service availability and continuance, people's acceptance and reasonability, accessibility to the society, affordability and quality. The effort made by BPJS is making a gradual health service system starting from first to advanced health service facility. However, in its implementation, some obstacles appear in its way, including:

1. The facilities and infrastructures have not fulfilled the applicable standards, such as rooms, classes, beds, health equipment and other supporting services due to the limited available service and fund; and

2. The needed medicines and expendable medical materials have not been adequately available. In fact, some BPJS participant patients' families complain for they have to pay more to purchase the medicines the hospital fails to provide as can be seen from the doctor's receipt to use those medicines other than what are provided by BPJS and to buy them in the drugstore the doctor recommends at the patient's own expense. [11]

Considering the foregoing, some formal issues are found to have hindered the implementation of legal protection to workers by BPJS for Manpower which can be divided into internal and external factors. The internal factors are the lengthy administrative process, less skilled Human Resource, and inadequate facilities. The external factors are employer's understanding, company's limited fund, less trustworthiness of BPJS for Manpower and, lastly, the fact that companies only register some of its workers. 


\section{Conclusion}

The legal issues in the implementation of Social Security System is related to the change of workers' rights to receive health insurance into their obligation to pay premium in order to receive health insurance. On the other hand, BPJS role in realizing the health service for workers is stilled hindered by internal and external factors. It is these issues which should be rectified to implement the social security system as mandated in Article 5 paragraph (1), Article 20, Article 28H paragraph (1), paragraph (2) dan paragraph (3) and Article 34 paragraph (1) and paragraph (2) of the 1945 Constitution.

\section{References}

1 http://bisnis.liputan6.com/read/3177528/13-juta-peserta-keluar-dari-bpjsketenagakerjaan accessed on December 17, 2017 at 15.30 WIB

2. H.R, Ridwan, Hukum Administrasi Negara (Rajagrafindo Persada, Jakarta, 2011)

3. I. Soepomo, Pengantar Hukum Perburuhan (Djambatan, Jakarta, 1971)

4. A. Khakim, Dasar-Dasar Hukum Ketenagakerjaan Indonesia (Citra Aditya Bakti, Bandung, 20140.

5. L. Husni, Pengantar Hukum Ketenagakerjaan, (Rajawali Press, Jakarta, 2015)

6. A. Sutedi, Hukum Perburuhan, (Sinar Grafika Offset, Jakarta, 2009).

7. T. Sudrajat, Hukum Birokrasi Pemerintah; Kewenangan dan Jabatan, (Sinar Grafika, Jakarta, 2017).

8. M.Husni, Jurnal Equality, 11, 87 (2006)

9. Department of Health of Indonesia, Penyelenggaraan Upaya Pelayanan Kesehatan Swasta Di Bidang Medik Spesialisitik. (Department of Health of Indonesia, 1996).

10. Trisna Widada, Agus Pramusinto and Lutfan Lazuardi, J. Ketahanan Nasional, 23, 204, (2017) 